\title{
Zoning Rural Area For The Development Of Annual Plants
}

\author{
Bariot Hafif $^{1}$, Junita Barus ${ }^{1}$ and Masganti ${ }^{2}$ \\ ${ }^{1}$ Lampung Assessment Institute for Agricultural Technology \\ Jl. Z.A. Pagar Alam No. Ia Bandar Lampung, 35145, Indonesia \\ Email: hafif_bariot@yahoo.co.id \\ ${ }^{2}$ Riau Assessment Institute for Agricultural Technology
}

\begin{abstract}
One strategy to protect land from degradation is to use the land according to their capability. Zoning of commodities is an effort in that direction and determination of commodities is based on the suitability of land with agronomic needs of crops and farming feasibility analysis. The purpose of this study was to determine the development zone of annual crops, based on the analysis of agro-ecological characteristics and agricultural viability. Analysis of land suitability for the cultivation of coffee, vanilla, pepper, cocoa, banana, durian, mango, and melinjo, found that land can be recommended for the development of the annual crops is about $\mathbf{2 9 , 2 3 0}$ ha from an area of $\mathbf{5 4 , 7 6 4}$ ha. The land was divided into six agro-ecological zones i.e. two zones at area with land slope of 3 $8 \%$, each covering an area of 2,737 ha at an altitude of $15-50 \mathrm{~m}$ above sea level (asl), and 12,008 ha at an altitude of 50-300 $\mathrm{m}$ asl, the two zone at area with land slope of 8-15\%, each covering 6119 ha at an altitude of $25-250 \mathrm{~m}$ asl and 1,221 ha at an altitude of $15-50 \mathrm{~m}$ asl, and two zones at area with land slope of $16-40 \%$, each covering an area of 1,101 ha at an altitude of 400-700 $\mathrm{m}$ asl, and 6,134 ha at an altitude of $400-500 \mathrm{~m}$ asl. The soil types found are Typic/Vitrandic Eutrudepts, Typic Hapludands, and Vitrandic Hapludalfs. This study recommends that the banana is a perennial plant with the most potential to be developed and has good economic prospects in almost all agro-ecological zones. Other commodities are also preferred, coffee and vanilla.
\end{abstract}

Keywords - Agro-ecological zones; land suitability; annual plant; rural area.

\section{INTRODUCTION}

Agro-ecological zoning of an area can be used as the basis of consideration for some applications are as an ingredient in evaluating the potential of an area for agricultural development [4]. Lack of sufficient environmental policies for sustainable use of lands as well as degradation of the land have revealed the importance of land suitability analysis for a land use planning [5].

The land in the area can be grouped based on land development potential and constraints when using agroecological assessment as the basis for the consideration of agriculture in rural development plans [3]. Agro-ecological or vegetative zone is a region divided by physiographic, climate and ecology [13], and the soil and geomorphologic environmental components are important agro-ecological variables [11]. To improve agricultural productivity in an area, the factors that affect plant growth must be identified [12]. Climate is the agro-ecological elements that are very real effect on the productivity of plants [7].

So far the use of a data base of land as a consideration in setting policy for the development of an area is not maximized. Considerations used by the farmers in choosing plants that will be developed tend to be based on commodity prices at that time. This means that farmers are still lacking in consideration of the sustainability of farming. Land use suitability assessment is an important fundamental work in rural planning [8]. It provides important reference for planning, planning management, planning implementation and planning evaluation, and land evaluation is the process of predicting the use potential of land on the basis of its attributes [15].

Zoning commodities to crop seeded either annual or seasonal crops, must consider the socio-economic and agroecological conditions. It will have an impact on lower production costs and better production quality, so that the competitiveness of commodities is also better [6]. The purpose of this study was to determine the development zone of annual crops in rural area, based on the analysis of agroecological characteristics and agricultural viability.

\section{MATERIALS AND METHODS}

Study area was Sub-district Panengahan, Ketapang, Palas and Sragi, South Lampung Regency, geographically situated between $105^{\circ} 35^{\prime}$ to $105^{\circ} 45^{\prime}$ East and $5^{\circ} 25$ 'to $6^{\circ}$ South and lies at an altitude of $0-1200 \mathrm{~m}$ asl, with the peak area is the 
highest mountain Raja Basa. Total of the study area was 54, 764 ha.

Annual crop zoning was done in two (2) phases; desk work and field work. Desk work was needed to construct a field map is a map that was used as a guide for land survey. Land units delineated through interpretation of landsat imagery and aided by the use of some base map such as administrative map, topographic map, and contour map of 1:50,000 scale. Next was a survey to identify land physiographic, land slope, soil drainage, altitude, climate data collection, and other properties of agro-ecology as the basis of the delineation of agro-ecological zones. Furthermore, a survey conducted in semi-detailed soil conditions to determine some of the quality of land that can be observed and measured directly in the field [14].

Land quality data observed in the field such as drainage conditions to estimate the availability of oxygen (oa), texture, effective soil depth, and \% coarse material to estimate root growth (rc), slope and erosion hazard for erosion hazard prediction (eh), inundation for flood hazard prediction (fh), rock surface (\%)) and outcrop (\%) for prediction of land preparation conditions, the toxicity / salinity (dS / m) (xc), sodicity (alkalinity) (ESP\%) and analysis of the chemical characteristics of the soil such as cation exchange capacity (CEC), base saturation (BS), $\mathrm{pH}$ and $\mathrm{C}$-organic for nutrient retention prediction (nr).

To evaluate the suitability of land in each agro-ecological zone, the data base as a result of the identification of soil morphology, soil sample analysis results data and climate data (average temperature and rainfall) to estimate the availability of water (wa), matched with the requirements of agronomic coffee (robusta and arabica), vanilla, pepper, cocoa, banana, durian, mango, and melinjo (G.gnemon).

Automatic program of land evaluation system (ALES), which also includes zoning commodities module, were used for evaluation of land suitability for the growth of various commodities [9]. The results of the analysis are in the form of land suitability classes for each commodity that is suitable (S1), is more suitable (S2), marginally suitable (S3) and not suitable $(\mathrm{N})$. For the class S2, S3, and N, each symbol will be equipped with additional symbols indicating growth limiting factors such as those mentioned earlier. Commodities that are considered suitable to the conditions of land will also be analyzed economic prospects. Parameters to analyze the economic feasibility of the plant were the Benefit Cost Ratio (B / C), Net Present Value (NPV), Internal Rate of Return (IRR) and breakeven point (BEP). A commodity is considered feasible if the $\mathrm{B} / \mathrm{C}>1$, NPV> 0 and IRR> discount rate $(17 \%)$ [17].

The end result of the analysis is the agricultural zoning map, scale 1:50,000 prepared using GIS (Geographic Information System) and Arc-View software [10].

\section{RESULTS AND DISCUSSION}

\section{A. Type of Soil}

The main soil order found was Inceptisols. At the great group is divided into an area of 17,837 ha Typic Eutrudepts and an area of 3,862 ha Vitrandic Eutrudepts. Typic Eutrudepts is mainly found on slopes $3-15 \%$, and Vitrandic Eutrudepts more dominant on slopes 3-25\%. Another order was found to be quite extensive Andisols. Great group of soil is classified as a Typic Hapludands and found an area of approximately 9,029 ha. This land stretched from flat to rugged conditions $(>40 \%)$. In addition to the two orders was also obtained Alfisols or Vitrandic Hapludafs. This soil is not very wide, is only about 169 ha. Other land classified as wetland. The main soil in wetland is Typic Endoaquepts, Typic Sulfaquents, Typic Psammaquents or Sulfic Endoaquepts. These soils are not recommended for annual crops.

Texture of Eutrudepts and Hapludands is loam, while Hapludafls is clay. The assessment of soil fertility was low categories for levels of C-organic and $\mathrm{N}$ total. The soil reaction was acidic to slightly acidic, $\mathrm{P}$ was high enough on Hapludands, and exchangeable $\mathrm{Ca}, \mathrm{Mg}$ and $\mathrm{K}$ were medium category in all soils and base saturation (BS) were classified as high category (Table 1).

\section{B. Climate}

Based on the calculation of Schmidt and Fergusson [2], most of the study area (District Panengahan and Ketapang) was under a $\mathrm{C}$ type climate with $1,617 \mathrm{~mm}$ rainfall / year and the wet months (rainfall $>100 \mathrm{~mm}$ ) for 6-7 months and months of dry (rainfall $<60 \mathrm{~mm}$ ) 5-6 consecutive months during the year. Average rainfall in wet months (NovemberApril) is $1,026 \mathrm{~mm}$ and in dry months (April-November) is about $762 \mathrm{~mm}$ [18]. Temperatures range from hot (isohyperthermic) to cool (iso-thermic) with average monthly temperatures range between $26.0-26.9^{\circ} \mathrm{C}$ and the average monthly humidity is between 77.1 - $84.5 \%$ (Fig. 1). Observations over 5 year shows the distribution of dry months and wet months are not evenly distributed (Fig. 2).

\section{Land Suitability for Annual Crops}

The analysis of land suitability for various annual crops such as cocoa, pepper, coffee, bananas, oranges, melinjo, coconut, rubber, and durian showed that of 28 land units were identified which can be categorized as highly suitable (S1) for the development of such annual crop is only on the land unit T113-R-2 (tectonic undulating terrain, tuff and sedimentary rocks, 3-8\% slope, deep, well drainage, texture medium, slightly acidic, Typic Eutrudepts), covering an area of 5,072 ha or $9.26 \%$ of total study area. Land that is somewhat suitable (S2) were found on the land unit V032H-3 (hilly volcanic, andesite, lava, 15-25\% slope, deep, well drainage, texture medium, slightly acid, Typic Hapludands), covering an area of 2,273 ha or $4.15 \%$ of the total area examined. The main problem in the $\mathrm{S} 2$ category of land is the danger of erosion (eh).

Land suitability classes of the most widely encountered is the category of marginal suitability (S3) with the major limiting factors of plant growth is the danger of erosion (eh), flood hazard (fh), the availability of oxygen to the roots (oa), development of roots (rc), and land preparation (lp). While for the land is not suitable $(\mathrm{N})$, major limiting factor is the development of roots (rc) or effective soil depth. 
TABLE I

PROPERTIES OF TYPIC EUTRUDEPTS, TYPIC HAPLUDANDS AND TYPIC HAPLUDALFS OF THE PANENGAHAN, KETAPANG, PALAS AND SRAGi, SOUTH LAMPUNG

\begin{tabular}{|c|c|c|c|c|c|c|c|c|c|}
\hline \multicolumn{2}{|l|}{ Soils } & \multicolumn{2}{|c|}{ Typic Eutrudepts } & \multicolumn{2}{|c|}{$\begin{array}{l}\text { Vitrandic } \\
\text { Eutrudepts }\end{array}$} & \multicolumn{2}{|c|}{$\begin{array}{l}\text { Typic } \\
\text { Hapludands }\end{array}$} & \multicolumn{2}{|c|}{ Typic Hapludalfs } \\
\hline Depth & $\mathrm{cm}$ & $0-30$ & $30-60$ & $0-30$ & $30-60$ & $0-30$ & $30-60$ & $0-30$ & $30-60$ \\
\hline Sand & $\%$ & 26.1 & 22.5 & 42.0 & 56.0 & 33.4 & 47.7 & 13.0 & 4.0 \\
\hline Silt & $\%$ & 46.8 & 34.0 & 41.0 & 33.0 & 30.4 & 34.0 & 37.0 & 40.0 \\
\hline clay & $\%$ & 27.1 & 43.5 & 17.0 & 11.0 & 36.2 & 18.3 & 50.0 & 56.0 \\
\hline $\mathrm{pH}(\mathrm{H} 2 \mathrm{O})$ & & 5.7 & 5.5 & 5.4 & 5.6 & 5.7 & 5.4 & 5.1 & 5.2 \\
\hline$(\mathrm{KCl})$ & & 5.1 & 4.6 & 4.7 & 4.4 & 5.0 & 4.2 & 4.4 & 4.5 \\
\hline $\mathrm{C}$ & $\%$ & 1.4 & 0.5 & 1.12 & 0.27 & 1.1 & 0.5 & 1.3 & 0.9 \\
\hline $\mathrm{N}$ & $\%$ & 0.2 & 0.1 & 0.13 & 0.04 & 0.1 & 0.1 & 0.2 & 0.1 \\
\hline $\mathrm{C} / \mathrm{N}$ & & 8.6 & 9.1 & 9.0 & 7.0 & 8.4 & 10.0 & 9.0 & 9.0 \\
\hline $\mathrm{P}_{2} \mathrm{O}_{5} \quad(\mathrm{HCl}$ & & & & & & & & & \\
\hline $25 \%)$ & $\mathrm{mg} / 100 \mathrm{~g}$ & 17.4 & 11.7 & 7.0 & 4.0 & 18.8 & 2.3 & 16.0 & 12.0 \\
\hline $\mathrm{K}_{2} \mathrm{O} \quad(\mathrm{HCl}$ & & & & & & & & & \\
\hline $25 \%)$ & $\mathrm{mg} / 100 \mathrm{~g}$ & 32.8 & 18.3 & 38.0 & 42.0 & 67.2 & 66.7 & 21.0 & 17.0 \\
\hline $\mathrm{P}_{2} \mathrm{O}_{5}$ (Bray 1 & $\mathrm{ppm}$ & 8.4 & 7.0 & 2.6 & 22.0 & 25.3 & 19.9 & 0.6 & 1.2 \\
\hline $\mathrm{Ca}^{2+}$ & $\mathrm{me} / 100 \mathrm{~g}$ & 10 & 7.6 & 4.42 & 3.48 & 10.6 & 1.7 & 2.9 & 2.8 \\
\hline $\mathrm{Mg}^{2+}$ & $\mathrm{me} / 100 \mathrm{~g}$ & 2.5 & 2.6 & 1.75 & 2.7 & 1.7 & 2.0 & 1.4 & 1.5 \\
\hline $\mathrm{K}^{+}$ & $\mathrm{me} / 100 \mathrm{~g}$ & 0.4 & 0.2 & 0.43 & 0.55 & 1.1 & 1.0 & 0.4 & 0.4 \\
\hline $\mathrm{Na}^{+}$ & $\mathrm{me} / 100 \mathrm{~g}$ & 0.2 & 0.3 & 0.18 & 0.15 & 0.3 & 0.3 & 0.2 & 0.3 \\
\hline CEC & $\mathrm{me} / 100 \mathrm{~g}$ & 12.5 & 11.3 & 6.2 & 5.7 & 13.7 & 6.1 & 9.1 & 8.4 \\
\hline BS & $\%$ & 93.2 & 86.1 & $>100$ & $>100$ & 61 & 72.5 & 53 & 60 \\
\hline $\mathrm{Al}^{3+}$ & $\mathrm{me} / 100 \mathrm{~g}$ & 0.1 & 0.2 & 0.0 & 0.0 & 0.1 & 1.7 & 0.1 & 0.1 \\
\hline
\end{tabular}

\section{Annual Plant Commodities Zoning}

From the combination of the suitability of land with crops of economic feasibility analysis (Table 2), obtained agro-ecological zones are recommended for the development of a variety of annual plants in the study area. Land recommended for the development of the annual crop of approximately 29,230 ha area. This area is divided into six zoning (Fig. 3).

The first zone is the IV/Deh covering 12,008 ha. This zone is rather flat (3-8\%), height of $50-300 \mathrm{~m}$ asl, soil is deep (Typic Hapludands and Vitrandic Eutrudepts), well drainage, texture medium, and the $\mathrm{pH}$ is slightly acidic.

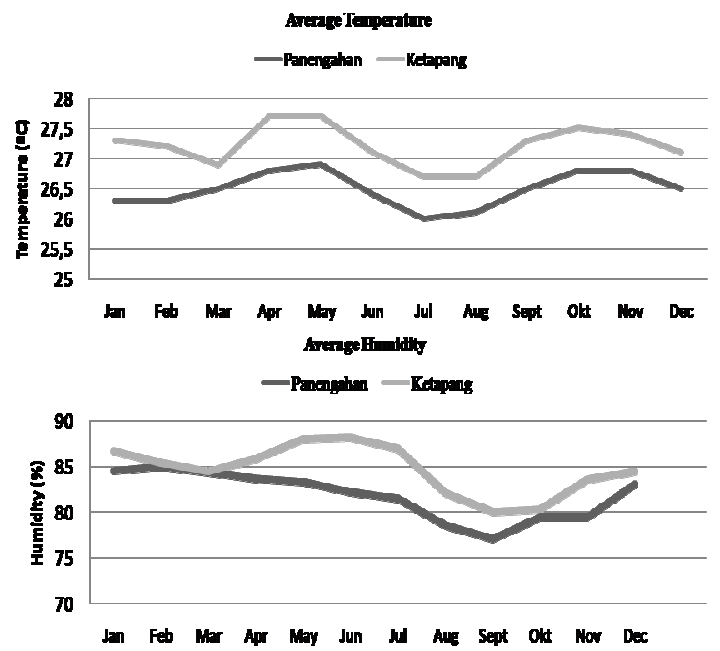

Fig 1 . The average temperature and humidity during the 5 years of observation in the District Panengahan and Ketapang, South Lampung.

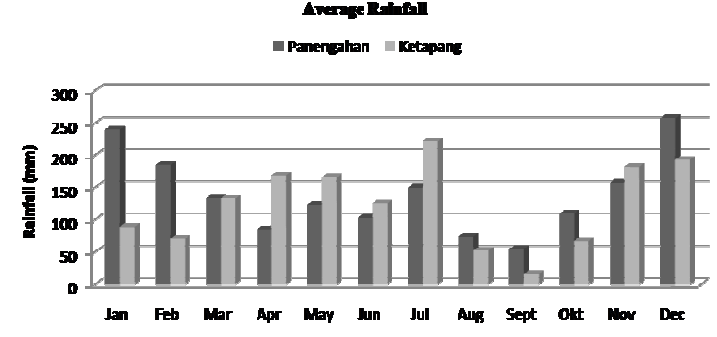

Fig 2. The average rainfall during the 5 years of observation in the District Panengahan and Ketapang, South Lampung.

Commodities that are recommended for this zone (the order of the most recommended), namely banana, coffee robusta, vanilla, cocoa, durian, melinjo, coffee robusta, and mango.

The second zone is still IV/Deh, an area of 2,737 ha with a height between $15-50 \mathrm{~m}$ asl, soil is depth, well drainage, texture medium, slightly acidic $\mathrm{pH}$ and soil type predominantly Typic Eutrudepts. This zone corresponds to commodity banana, vanilla, cocoa, durian, melinjo, coffee robusta, mango.

The third is agro-ecological zones III/Deh area of 6,119 ha, the slope of $8-15 \%$, altitude of $25-250 \mathrm{~m}$ asl. The character of this zone is generally deep, well drainage, texture medium, slightly acidic $\mathrm{pH}$ and the predominant soil type is Typic Hapludands or Vitrandic Eutrudepts. This zone is recommended for commodities bananas, coffee arabica, vanilla, cocoa, durian, melinjo, coffee robusta, and mango.

The Fourth is zones III/Deh, an area of 1,221 ha, 8-15\% slope, the height of $300-500 \mathrm{~m}$ asl, the soil is deep, well drainage, texture medium, slightly acidic $\mathrm{pH}$, and soil type predominantly Typic Eutrudepts. Zone 4 is suitable for all commodities coffee arabica, vanilla, cocoa, durian, melinjo, coffee robusta, and mango. 
TABLE II

THE RESULTS OF THE ANALYSIS OF THE ECONOMIC VIABILITY OF SOME CROPS WHEN DEVELOPED IN THE PANENGAHAN, KETAPANG, PALAS AND SRAGI, SOUTH LAMPUNG

\begin{tabular}{|l|c|c|c|c|}
\hline \multirow{2}{*}{ Commodities } & \multicolumn{4}{|c|}{ Economic Analysis } \\
\cline { 2 - 5 } & B/C & NPV (Rp) & $\begin{array}{c}\text { IRR } \\
(\%)\end{array}$ & $\begin{array}{c}\text { BEP } \\
\text { (months) }\end{array}$ \\
\hline Banana & 1.82 & 4.653 .472 & 49 & 18 \\
Mango & 5.24 & 3.184 .703 & 28 & 75 \\
Cocoa & 4.71 & 30.664 .785 & 30 & 52 \\
Coffee & 4.83 & 13.410 .004 & 48 & 49 \\
Pepper & 3.35 & 14.211 .240 & 19 & 85 \\
Vanilla & 5.54 & 26.329 .310 & 32 & 65 \\
Melinjo & 8.09 & 6.367 .809 & 48 & 50 \\
Coconut & 7.3 & 8.329 .178 & 17 & 134 \\
Durian & 3.39 & 18.164 .381 & 19 & 109 \\
\hline
\end{tabular}

The fifth agro-ecological zones is II/Deh covering 1,101 ha, the slope of $16-40 \%$, altitude $400-700 \mathrm{~m}$ above sea level with the characters deep, well drainage, smooth texture, slightly acidic $\mathrm{pH}$ and soil category of Typic Eutrudepts or Vitrandic Hapludalf. These fifth zones correspond to banana, pepper, vanilla, and coconut.

The sixth is still agro-ecological zones II/Deh with an area of 6,134 ha, $16-40 \%$ slope, altitude $400-500 \mathrm{~m}$ asl. The soil is deep, well drainage, texture medium, slightly acid, and the dominant soil types are associated with Lithic Typic Hapludands and Eutrudepts. This zone is suitable for bananas, coffee arabica, vanilla, cocoa, durian, melinjo, coffee robusta, and mango.

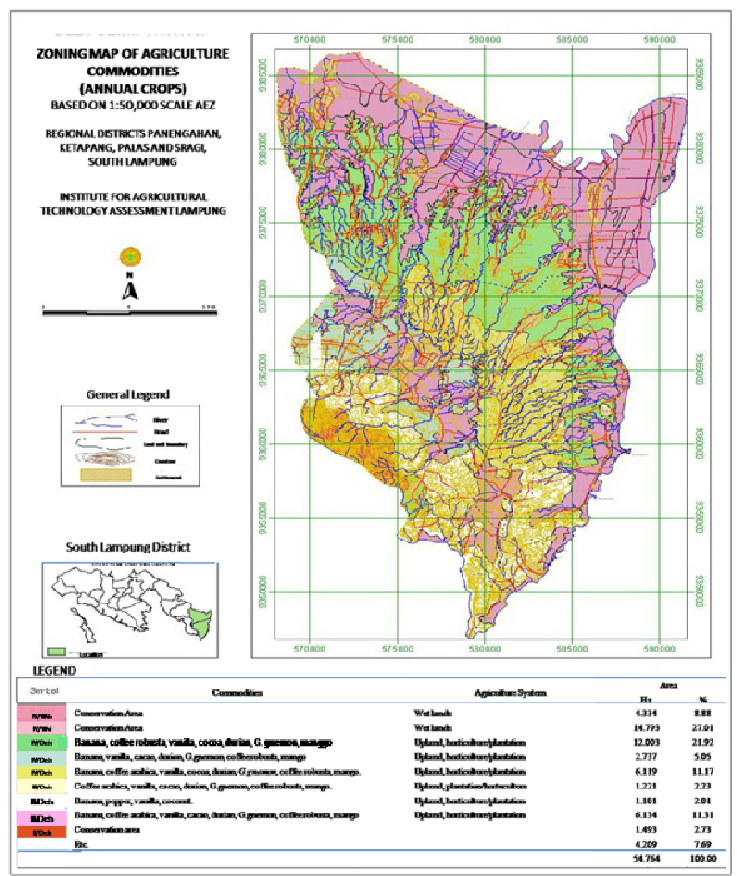

Fig 3. Zoning map of annual crops for district Panengahan, Ketapang, Palas and Sragi, South Lampung

Results of the study showed that the most recommended annual crop developed is banana. Of the six (6) zones only one (1) agro-ecology is not recommended for the development of banana. One key factor why the bananaelect is the payback period (break-even point) of banana farms are much faster and also the market for sales of bananas both local market and domestic market is very open, especially markets in West Java including Jakarta. Under conditions of limited capital and farmers are still difficult to access capital resources and the cost of banana cultivation is not too much, then the farmers in the area should focus more on the banana farms.

\section{CONCLUSIONS}

Land suitability analysis for Panengahan, Ketapang, Palas and Sragi, South Lampung, covering an area of 54,764 ha, for the development of banana, coffee, vanilla, pepper, cocoa, durian, melinjo, and mango getting land suitability classes that are dominated by marginal suitability (S3) with growth limitation factors were the danger of erosion (eh), the availability of oxygen to the roots (oa), root condition (rc) and land preparation (lp) and flood hazard (fh) at low land area.

Land with a very suitable category (S1) for all commodities was only an area of 5,072 ha or $9.26 \%$ of total study area. Land that can be recommended for the development of the annual crop is about 29,230 ha, which was divided into six agro-ecological zones: two zones IV/Deh (land slope of 3-8\%), each covering an area of 2,737 ha at an altitude of 15-50 m asl, and 12,008 ha at an altitude of 50-300 m asl, the two zone III/Deh (land slope of 8-15\%), each covering 6119 ha at an altitude of $25-250 \mathrm{~m}$ asl and 1,221 ha at an altitude of $15-50 \mathrm{~m}$ asl and two zones II/Deh (land slope of 16-40\%), each covering an area of 1101 ha at an altitude of 400-700 m asl and 6,134 ha at an altitude of $400-500 \mathrm{~m}$ asl. The dominant soil types found in the height of $15-50 \mathrm{~m}, 50-300 \mathrm{~m}$, and 300-700 m asl, respectively, are Typic Eutrudepts, Typic Hapludands and Vitrandic Eutrudepts, Lithic Typic Hapludands and Typic Eutrudepts or Vitrandic Hapludalf. This study recommends that the banana is a perennial plant with the most potential to be developed and has good economic prospects in almost all agro-ecological zone. Other commodities are also preferred, coffee and vanilla.

\section{ACKNOWLEDGMENT}

The authors gratefully acknowledge the support provided by Lampung Assessment Institute for Agricultural Technology, (AIAT). The authors also thank technical assistances from the staffs of Lampung AIAT; Staffs of Central Research and Development of Agricultural Land Resources, and the Chemistry Laboratory of the Indonesian Soil Research Institute.

\section{REFERENCES}

[1] Amien, L.I. 1997. Karakterisasi, Deliniasi dan Analisis Agroekologi. Makalah pada Apresiasi Metodologi Analisis Zona Agroekologi di Bogor, November 1997.

[2] Badan Meterologi dan Geofisika Lampung. 1999. Prediksi Musim Kemarau Panjang tahun 2002. Buletin BMG Lampung. Maret 2001

[3] FAO. 1996. Agro-Ecological Zoning, Guidelines. FAO Soils Bulletin 73. Roma.

[4] Fischer G., Shah M., H. van Velthuizen, and F. Nachtergaele. 2006 Agro-Ecological Zones Assessment. Oxford, UK.

[5] Jafari, S. and N. Zaredar. 2010. Land suitability analysis using multi attribute decision making approach. International Journal of Environmental Science and Development, Vol.1 (5): 441-445. 
[6] Karama, Syarifuddin. 1999. Pembangunan Pertanian Untuk Menempatkan Pertanian Sebagai Andalan. Prosiding Seminar Nasional Sumberdaya Tanah, Iklim dan Pupuk. Bogor, $6-8$ Desember 1999. Pusat Penelitian Tanah dan Agroklimat.

[7] Kayode O.A. 2010. The effect of weather on coco production in different agroecological zones in Nigeria. Word Journal Of Agriculture Science 6 (5):609-614

[8] Lingjun, L., He Zong, and Hu yan. 2008. Study on land use suitability assessment of urban-rural planning based on remote sensing-A Case Study Of Liangping In Chongqing. The International Archives of the Photogrammetry, Remote Sensing and Spatial Information Sciences. Vol. XXXVII. Part B8. Beijing.

[9] Marwan, H., D. Djaenuddin, H. Subagyo, S. Hardjowigeno dan E.R. Jordan. 2000. Petunjuk Pengoperasian Program Sistem Otomatisasi Penilaian Lahan (Automated Land Evaluation System/ALES). Versi 3.0, September 2000. Puslitanak, Bogor.

[10] Mulyani, A. 2001. Petunjuk Teknis Penyusunan Peta Pewilayahan Komoditas Pertanian Berdasarkan Zona Agroekologi (ZAE). Puslitbangtanak Bogor.

[11] Pirbalouti, A.G. 2009. GIS-based land suitability evaluation for rapeseed oil crop. Journal of Food, Agriculture \& Environment Vol.7 $(3 \& 4): 837-840$.
[12] Quddus M.A. 2009. Crop production growth in different agroecological zones of Bangladesh. J. Bangladesh Agril. Univ. 7(2): 351-360.

[13] Rahim, S.M.A., S. Hasnain, and J. Farkhanda. 2011. Effect of nitrogen and phosphorous on Farm Plantations in various agroecological zones of Punjab,Pakistan. African Journal of Environmental Science and Technology Vol. 5(11), pp. 964-971

[14] Ritung S., Wahyunto, F. Agus, dan H. Hidayat. 2007. Panduan Evaluasi Kesesuaian Lahan. Balai Penelitian Tanah dan World Agroforestry Centre.

[15] Rossiter, D.G, 1996. A theoretical framework for land evaluation. GEODERMA, 72: 165-202

[16] Sudaryanto, B. 2002. zonasi Agroekologi Propinsi Lampung. Balai Pengkajian Teknologi Pertanian Lampung.

[17] Soekartawi. 2006. Analisis Usaha Tani. Jakarta. Universitas Indonesia.

[18] Surmaini, E. dan G. Irianto. 2001. Karakteristik Dampak El-Nino Terhadap Curah Hujan dan Pergeseran Musim di Lampung. Prosiding Seminar Nasional Pengelolaan Sumberdaya Lahan dan Pupuk. Bogor, 30 - 31 Oktober 2001. Puslitbangtanak. 